\title{
Bioactive compounds and physical attributes of Cornus mas genotypes through multivariate approaches
}

\author{
Bünyamin Demir ${ }^{1, *}$, Bahadır Sayinci ${ }^{2}$, Ahmet Sümbü̈l${ }^{3}$,Mehmet Yaman ${ }^{4}$, \\ Ercan Yildiz, Necati Çetin ${ }^{5}$, Orhan Karakaya ${ }^{6}$, Sezai Ercişli $^{7}$
}

\author{
${ }^{1}$ Department of Mechanical Engineering, Faculty of Engineering, Mersin University, Çiftlikköy Campus, \\ 33343 Yenişehir/Mersin, Turkey \\ ${ }^{2}$ Department of Mechanical Engineering, Faculty of Engineering, Mersin University, Çiftlikköy Campus, \\ 33340 Yenişehir/Mersin, Turkey \\ ${ }^{3}$ Department of Plant and Animal Production, Suşehri Timur Karabal Vocational School, Sivas Cumhuriyet University, \\ 58600 Suşehri/Sivas, Turkey \\ ${ }^{4}$ Department of Horticulture, Faculty of Agriculture, Erciyes University, 38280 Talas/Kayseri, Turkey \\ ${ }^{5}$ Department of Biosystem Engineering, Faculty of Agriculture, Erciyes University, 38280 Talas/Kayseri, Turkey \\ ${ }^{6}$ Department of Horticulture, Faculty of Agriculture, Ordu University, 52200 Altınordu/Ordu, Turkey \\ ${ }^{7}$ Department of Horticulture, Faculty of Agriculture, Atatürk University, 25240 Yakutiye/Erzurum, Turkey
}

\begin{abstract}
Cornelian cherry fruits are quite rich in bioactive compounds. Natural colour, rich flavonoids and anthocyanins and high antioxidant activity have made the fruits a natural drug. In the present study, antioxidant activity, total flavonoids and total phenolics of naturally growing 18 cornelian cherry genotypes with different phenotypic characteristics were determined. Size and shape parameters of the genotypes were also determined with the image-processing method; sphericity, elongation and shape index were calculated and shapes of two-dimensional fruit images were compared with elliptic Fourier analysis. Antioxidant activity, total flavonoid contents and total phenolic amounts of the genotypes were varied between 55.062 and $152.420 \mathrm{mmol} \mathrm{TE} \cdot \mathrm{kg}^{-1}, 286.40$ and $2,882.80 \mathrm{mg} \mathrm{QE} \cdot \mathrm{kg}^{-1}$, and 2,644.80 and 12,959.00 $\mathrm{mg} \mathrm{GAE} \cdot \mathrm{kg}^{-1}$, respectively. Multivariate variance analysis conducted based on physical characteristics revealed that six genotypes were different from the others. Shape analysis with Elliptic Fourier method revealed that the majority of present cornelian cherry genotypes had an oval appearance and a small portion of them had a drop-like appearance. According to discriminant analysis and Hotelling's pair-wise comparison tests, there were five different shape groups for present genotypes. A single genotype was placed into one of these groups, thus it was determined that this genotype was totally different in shape from the others.
\end{abstract}

Keywords: cranberry genotypes, elliptic Fourier analysis, shape features, shape index

\section{INTRODUCTION}

Fruits are a very diverse group and have been evaluated in industrial crops besides their fresh consumption for centuries (Ersoy et al., 2018a; Colak et al., 2019; Gundesli et al., 2019; Mertoglu et al., 2019; Okan et al., 2019). One of them, Cornus genus of Cornaceae family has about 65 species. These species are widespread in the northern hemisphere, southern and central Europe, southwestern Asia, America and eastern Africa (Eyde, 1988). Majority of species in Cornus genus are grown as ornamental plants and Cornus mas L. is the most significant of these species economically (Ercisli et al., 2008; Bijelic et al., 2011). Cornelian cherry (Cornus 
mas L.) has been cultured for about 4,000 years and has a natural spread over the large range of geographies extending from Caucasus, Turkey, Bulgaria, Romania and Italy to Europe (Klimenko, 2004; Brindza et al., 2009; Szot et al., 2019a). In Turkey, cornelian cherry naturally grows under suitable climate conditions of Mediterranean, Aegean, Marmora and Black Sea regions within mountains, forests and valleys of several provinces (TUBİVES, 2020).

World annual cornelian cherry production is around 722.684 tons and the USA with an annual production of 404.880 tons is the leading producer of the world. The USA is, respectively, followed by Canada (195.196 tons), Chile (106.180 tons), Turkey (11.481 tons), Azerbaijan (2.874 tons) and Romania (581 tons) (FAOSTAT, 2018).

Horticulturally, cornelian cherry is classified under stone fruits group. It is a self-incompatible species, thus foreign-pollinated. With the aid of foreign-pollination, seed-propagated cornelian cherry genotypes with different genetic characteristics generated quite a rich population adapted to different conditions of different regions of Turkey. With such a rich population, cornelian cherry fruits exhibit great variations based on the regions as well as in shape, size, quality and colouration attributes. Shapes of cornelian cherry fruits vary from elliptical to cylindrical (Selçuk and Özrenk, 2011); fruit skin colours vary from yellow and cream to pink, red and dark red; fruit flesh colour is red, fruits are juicy with acrid, sour-sweetish taste (Didin et al., 2000; Klimenko, 2004; Tural and Koca, 2008).

Phenolics give an acrid taste to cornelian cherry fruits, thus they are not consumed much in fresh forms, unless its maturation is complete, but fresh forms are used in fruit juice, fruit-flavoured yoghurt, compote, marmalade, jam, jelly, tarhana, dried fruit roll-up and alcoholic and non-alcoholic beverages; dried forms are either consumed directly or used in local meals, salads and compote (Tural and Koca, 2008; Celep et al., 2013; Ozgen, 2015; Bozdogan, 2017). Cornelian cherry plants are not only used for fruits but also for landscape arrangements as an ornamental plant because of long flowering durations and yellow colour tone of the flowers (Da Ronch et al., 2016). Woods of cornelian cherry trees are also used in the furniture industry and especially in the manufacture of walking sticks (Mohsenin, 1986).

With the knowledge and consciousness about the health effects of fruit substances, fruits are either consumed directly or processed into different forms by the food industry. Besides direct consumptions, cornelian cherry fruits are also used as preservative or colourant in foodstuffs (Akpunar, 2015; Coksoyler, 2018; Ergezer et al., 2018; Elgin, 2019). While cornelian cherry fruits are used in the food industry, the other parts of the plants are used in the health sector against various diseases (Mikaili et al., 2013). With the specific aroma and colour substances, fruits are also used in cosmetics and dye industry (Akpunar, 2015; Coksoyler, 2018).

Previous researches revealed that cornelian cherry fruits were rich in vitamin $\mathrm{C}$, organic acids, phenolics, antioxidants, minerals and the other bioactive compounds (Kucharska, 2012; West et al., 2012; Deng et al., 2013; Akpunar, 2015). Thanks to its rich and diverse bioactive compounds, cornelian cherry fruit and its products have various health benefits, especially in obesity, cardiovascular disorders, diarrhoea and diabetes (West et al., 2012; Deng et al., 2013; Mikaili et al., 2013; Kucharska et al., 2015).

Several types of research pointed out the prominence of cornelian cherry fruits in terms of fruit composition. The nutritional values reported by the USDA clearly indicate such a prominence of cornelian cherry fruits. $100 \mathrm{~g}$ cornelian cherry fruits contain abundant quantities, especially, of vitamin C (14 mg), other vitamins, carbohydrate (11.97 g), sugar (4.27 g) and total dietary fibre (3.6 g). Cornelian cherry fruits also contain remarkable potassium $(80 \mathrm{mg})$, phosphorus (11 $\mathrm{mg})$, magnesium $(6 \mathrm{mg}$ ) and other element contents (FoodData Central, 2019).

The objectives of the present study for 18 cornelian cherry genotypes exhibiting quite different phenotypic characteristics within narrow geography such as Mesudiye town of Ordu province were set as to:

- assess variations with some biochemical characteristics,

- identify superior genotypes with high antioxidant activity and phenolic compounds, thus, providing material for further breeding studies,

- determine physical attributes (size, surface area, elongation, sphericity) of cornelian cherry genotypes for design and development of postharvest processing systems,

- put forth and compare shape attributes with the aid of elliptic Fourier analysis.

\section{MATERIALS AND METHODS}

\section{Cornelian cherry genotypes}

Seed-propagated cornelian cherry genotypes in Mesudiye town of Ordu province constituted the material of the present study. A total of 100 fruits were taken from each genotype. Collected fruits were placed into plastic boxes and transported to the laboratory in cooling thermos bottles.

\section{Nutritional attributes}

Experiments were conducted in 5 replicates with 20 fruits in each replicate. Stones of fruits were taken out with a stainless-steel knife and resultant flesh was homogenized in a blender. Homogenized fruit samples were placed into falcon tubes (about $50 \mathrm{~g}$ ) and preserved at $-20^{\circ} \mathrm{C}$ until bioactive compound analyses.

\section{DPPH antioxidant activity (free radical scavenging activity)}

Fruit 1.1-diphenyl-2-picryl-hydraziyl (DPPH) antioxidant activity was determined with the aid of modified method of Brand-Williams et al., (1995). For analysis, 
$0.26 \mathrm{mM}$ DPPH solution was prepared. Then, $100 \mu \mathrm{L}$ fruit extract was supplemented with $2,900 \mu \mathrm{L}$ ethyl alcohol and $1 \mathrm{~mL}$ DPPH solution. The resultant mixture was vortexed for $30 \mathrm{~min}$ and kept at dark. Sample absorbance readings were performed in a spectrophotometer at $517 \mathrm{~nm}$ wavelength. Results were expressed in $\mu$ mol Trolox equivalent (TE) $\cdot \mathrm{kg}^{-1} \mathrm{mmol}$ of fresh weight.

\section{Total flavonoid content}

Sample total flavonoid content was determined with the aid of the method recommended in Chang et al., (2002). Fruit extracts $(1,000 \mu \mathrm{L})$ were supplemented with $3.3 \mathrm{~mL}$ methanol, then with $0.1 \mathrm{~mL} 10 \%$ $\mathrm{AlCl}_{3} \cdot 6 \mathrm{H}_{2} \mathrm{O}$ and $0.1 \mathrm{~mL}$ of $1 \mathrm{M}$ potassium acetate $\left(\mathrm{CH}_{3} \mathrm{COOK}\right)$. Spectrophotometer readings were performed at $415 \mathrm{~nm}$ wavelength and total flavonoid contents were expressed in quercetin equivalent $\left(\mathrm{mg} \mathrm{QE} \cdot \mathrm{kg}^{-1}\right)$ of fresh weight.

\section{Total phenolics}

Folin-Ciocalteu's method was used to determine total phenolics of the samples. Initially, $500 \mu \mathrm{L}$ fresh fruit extract was supplemented with $4.2 \mathrm{~mL}$ distilled water, then with $100 \mu \mathrm{L}$ Folin-Ciocalteu reagent and $2 \%$ sodium carbonate $\left(\mathrm{Na}_{2} \mathrm{CO}_{3}\right)$. The resultant solution was incubated for $2 \mathrm{~h}$. Following the incubation, spectrophotometer readings were performed at $760 \mathrm{~nm}$ wavelength and the results were expressed in gallic acid equivalent (mg GAE $\cdot \mathrm{kg}^{-1}$ ) of fresh weight (Beyhan et al., 2010).

\section{Imaging methodology}

Samples were named between G1 and G18 for 18 genotypes (Figure 1). To determine the size and the shape attributes of each genotype, 75 cornelian cherry samples were placed over a lightbox in $5 \times 15$ matrix arrangement. Nikon D90 model camera was used to take the images of fruits at horizontal and vertical

Genotypes $\begin{gathered}\text { Horizontal } \\ \text { orientation }\end{gathered}$

Figure 1. Images of cornelian cherry genotypes at horizontal and vertical orientations. 
orientations. Imaging was performed from standard height of $50 \mathrm{~cm}$.

\section{Physical characteristics}

Physical characteristics of cornelian cherry fruits were determined with the aid of the image processing method. SigmaScan Pro v.5.0 software was used to determine the size and shape parameters. Length (L), width (W), thickness (T), projection area (PA), equivalent diameter (ED) and perimeter (P) measurements of cornelian cherry samples imaged at horizontal and vertical orientations were directly made with the aid of the software (Figure 2). The other size and shape parameters of cornelian cherry fruits and equations used to determine these parameters are provided in Table 1.

\section{Elliptic Fourier analysis}

Elliptic Fourier analysis (EFA) includes the stages of (i) formation of the points defining the closed contour of two-dimensional geometry, (ii) determination of $x$ and $y$ coordinates of each point over the contour and (iii) transformation of coordinates into a mathematical function and obtaining function coefficients defining the shape (Say1nc1, 2016). Function coefficients are generated based on the number of harmonics and each harmonic generates four Fourier coefficients $\left(a_{n}, b_{n}\right.$, $c_{n}$ and $d_{n}$ ). The $a_{n}$ and $b_{n}$ coefficients correspond to $x$ coordinates and $c_{n}$ and $d_{n}$ coefficients correspond to $y$ coordinates of the contour (Neto et al., 2006; ÖzkanKoca, 2012).

SHAPE (version 1.03) software was used to compare the geometry of cornelian cherry genotypes identified through the EF method (Iwata and Ukai, 2002). For analysis in software, fruit images were converted into 24-bit *bmp files. EFA and statistical assessments were performed with the use of four sub-modules; (i) 'ChainCoder' module was used for image processing and shape contour generation, (ii) 'Chc2Nef' module was used to normalize contour codes and to get elliptic Fourier descriptors, (iii) 'PrinComp' module was used for principal component analysis (PCA) of descriptors and to generate component scores and (iv) 'PrinPrint'

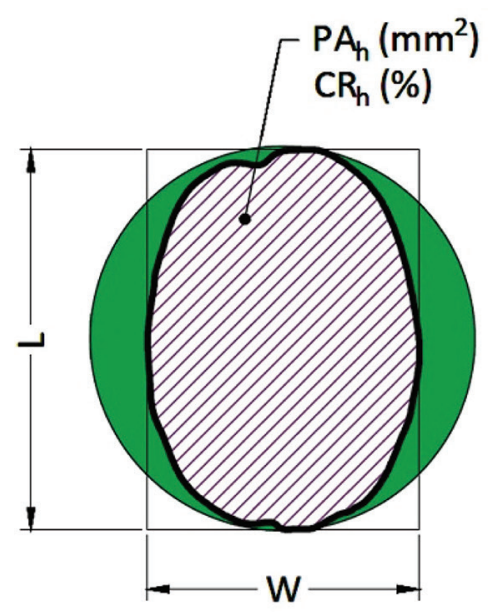

Horizontal orientation

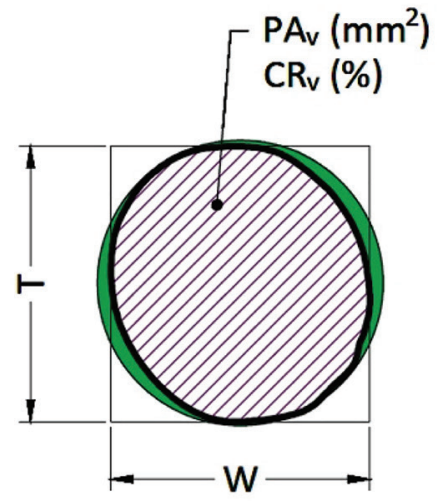

Vertical orientation

Figure 2. Basic sizes and notations for any cornelian cherry genotypes.

Table 1. Some size and shape parameters of cornelian cherry fruits

\begin{tabular}{lll}
\hline Physical features & Equation & Reference \\
\hline Geom. mean diameter $(\mathrm{mm})$ & $D_{g}=\sqrt[2]{L \cdot W \cdot T}$ & Kara (2017) \\
Surface area $\left(\mathrm{cm}^{2}\right)$ & $S A=\pi \cdot D_{g}^{2}$ & Olajide and Ade-Omowaye (1999) \\
Sphericity (\%) & $\varphi=\left(\mathrm{D}_{g}^{2} / \mathrm{L}\right) \cdot 100$ & Mohsenin (1986) \\
Shape index & $S I=2 \cdot L /(W+T)$ & Ercisli et al. (2012) \\
Shape factor & $S F=4 \cdot \pi \cdot P A / P^{2}$ & Sayinci et al. (2015a) \\
Elongation at horizontal & $E_{h}=L / W$ & Firatligil-Durmuş et al. (2010) \\
Elongation at vertical & $E_{v}=W / T$ & - \\
Coating rate (\%) at horizontal & $C R_{h}=\left(4 \cdot P A / \pi \cdot L^{2}\right) \cdot 100$ & - \\
Coating rate (\%) at vertical & $C R_{v}=\left(4 \cdot P A / \pi \cdot W^{2}\right) \cdot 100$ & - \\
\hline
\end{tabular}


module was used to visualise shape variations of fruit image contours. Analyses were conducted over 20 harmonics.

\section{Statistical analysis}

Nutritional attributes of cornelian genotypes were subjected to analysis of variance at $95 \%$ significance level by using one-way ANOVA procedure and statistically significant differences among the genotypes were revealed with the aid of Duncan's multiple comparison test. Statistical analyses were performed with the use of SPSS v.23.0 software.

One-way ANOVA was used to test the differences in size and shape parameters of cornelian cherry genotypes. Significant means were compared with the use of Tukey's multiple comparison test at 95\% significance level. PCA was performed to elucidate the relationships between size and shape parameters of the cornelian cherry genotypes. Eigen statistics were provided for principle components presenting the relationships between the genotypes. Factor loads were used to present the differences between the genotypes over a scatter chart.

Shape contours of cornelian cherry images were normalised to get elliptic Fourier scores presenting common variance. The components explaining the variance between these scores were visualised and differences between the genotypes were determined with the aid of multivariate analysis of variance (MANOVA). In the significance test of variance,
'Wilks's Lambda' and 'Pillai Trace' statistics were used. Pair-wise comparisons were made with the aid of Bonferroni-correction test (Bonferroni corrected $P$ values). Statistical analyses were conducted with the use of PAST v.3.25 software (Hammer et al., 2001).

For a visual comparison of differences between the genotypes, PC scores obtained from elliptic Fourier descriptors were used and these scores were subjected to discriminant analysis. At the end of this analysis, centroid coordinates of each genotype were determined, and visual similarities of the genotypes were presented over a scatter chart.

\section{RESULTS AND DISCUSSION}

\section{Biochemical characteristics of cornelian cherry genotypes}

There were significant differences in antioxidant activity, total flavonoids and total phenolics of the seed-propagated cornelian cherry genotypes $(p<0.05)$ (Table 2).

The greatest antioxidant activity was obtained from G13 (152.420 mmol TE $\left.\cdot \mathrm{kg}^{-1}\right)$, G14 (152.180 mmol $\left.\mathrm{TE} \cdot \mathrm{kg}^{-1}\right)$ and G11 $\left(151.943 \mathrm{mmol} \mathrm{TE} \cdot \mathrm{kg}^{-1}\right)$, which were all placed into the same statistical group. The lowest antioxidant activity was obtained from G10 $(55.062 \mathrm{mmol}$ $\left.\mathrm{TE} \cdot \mathrm{kg}^{-1}\right)$ and $\mathrm{G} 18\left(59.670 \mathrm{mmol} \mathrm{TE} \cdot \mathrm{kg}^{-1}\right)$ genotypes that have yellow fruits.

Table 2. Biochemical characteristics of cornelian cherry genotypes

\begin{tabular}{|c|c|c|c|}
\hline Genotypes & $\begin{array}{c}\text { Antioxidant activity } \\
(\mathrm{DPPH})\left(\mathrm{mmol} \mathrm{TE} \cdot \mathrm{kg}^{-1}\right)\end{array}$ & $\begin{array}{l}\text { Total flavonoids } \\
\left(\mathrm{mg} \mathrm{QE} \cdot \mathrm{kg}^{-1}\right)\end{array}$ & $\begin{array}{l}\text { Total phenolics } \\
\left(\mathrm{mg} \mathrm{GAE} \cdot \mathrm{kg}^{-1}\right)\end{array}$ \\
\hline G1 & $94.786 \pm 0.681 \mathrm{~g}^{*}$ & $391.80 \pm 11.77 \mathrm{~m}^{*}$ & $3,603.20 \pm 13.78 \mathrm{~m}^{*}$ \\
\hline G2 & $77.316 \pm 0.931 \mathrm{j}$ & $484.60 \pm 21.05 \mathrm{kl}$ & $2,644.80 \pm 26.99 p$ \\
\hline G3 & $96.669 \pm 0.475 \mathrm{~g}$ & $819.20 \pm 17.38 \mathrm{i}$ & $6,124.40 \pm 17.80 \mathrm{~h}$ \\
\hline G4 & $88.026 \pm 0.731 \mathrm{~h}$ & $537.00 \pm 11.73 \mathrm{jk}$ & $4,167.00 \pm 41.35 \mathrm{j}$ \\
\hline G5 & $89.938 \pm 1.196 \mathrm{~h}$ & $497.80 \pm 9.98 \mathrm{jkl}$ & $4,159.20 \pm 24.58 \mathrm{j}$ \\
\hline G6 & $70.661 \pm 0.333 \mathrm{k}$ & $451.20 \pm 11.42 \mathrm{~lm}$ & $3,865.00 \pm 16.631$ \\
\hline G7 & $144.861 \pm 0.546 \mathrm{c}$ & $2,882.80 \pm 27.38 \mathrm{a}$ & $10,609.40 \pm 84.28 \mathrm{c}$ \\
\hline G8 & $138.114 \pm 0.592 \mathrm{e}$ & $1,263.60 \pm 19.88 \mathrm{f}$ & $5,248.40 \pm 24.19 \mathrm{i}$ \\
\hline G9 & $96.310 \pm 1.009 \mathrm{~g}$ & $503.40 \pm 33.37 \mathrm{jkl}$ & $3,987.00 \pm 13.74 \mathrm{k}$ \\
\hline G10 & $55.062 \pm 0.505 \mathrm{~m}$ & $286.40 \pm 12.35 \mathrm{n}$ & $3,463.60 \pm 25.68 n$ \\
\hline G11 & $151.943 \pm 0.429 \mathrm{a}$ & $1,571.80 \pm 21.46 \mathrm{e}$ & $9,374.20 \pm 42.80 \mathrm{~d}$ \\
\hline G12 & $147.095 \pm 0.244 \mathrm{~b}$ & $1,889.80 \pm 16.56 \mathrm{c}$ & $8,719.40 \pm 61.75 \mathrm{e}$ \\
\hline G13 & $152.420 \pm 0.423 \mathrm{a}$ & $1,818.20 \pm 28.98 \mathrm{~d}$ & $11,355.00 \pm 48.58 \mathrm{~b}$ \\
\hline G14 & $152.180 \pm 0.289 \mathrm{a}$ & $2,070.40 \pm 47.00 \mathrm{~b}$ & $12,959.00 \pm 33.09 \mathrm{a}$ \\
\hline G15 & $140.656 \pm 0.566 \mathrm{~d}$ & $1,083.40 \pm 23.64 \mathrm{~h}$ & $8,513.80 \pm 31.80 \mathrm{f}$ \\
\hline G16 & $120.470 \pm 0.969 \mathrm{f}$ & $1,160.60 \pm 25.62 \mathrm{~g}$ & $7,498.60 \pm 40.08 \mathrm{~g}$ \\
\hline G17 & $82.401 \pm 0.751 \mathrm{i}$ & $459.00 \pm 12.421$ & $4,216.60 \pm 50.07 \mathrm{j}$ \\
\hline G18 & $59.670 \pm 0.7181$ & $556.80 \pm 20.12 \mathrm{j}$ & $3,233.60 \pm 30.07 \mathrm{o}$ \\
\hline
\end{tabular}

*Means followed by the same letter in the same column are not different as determined by the Tukey test at $5 \%$ significance level. 
Present findings on antioxidant capacity of seedpropagated cornelian cherry genotypes were found higher than the values reported in previous studies. Dragovic-Uzelacetal.(2007)conductedastudyinCroatia and reported DPPH-free radical scavenging activity of fruit extracts of two cornelian cherry genotypes as between 33.41 and $39.89 \mathrm{mmol}$ Trolox $\cdot \mathrm{kg}^{-1}$, Cosmulescu et al. (2019) conducted a study in Romania and reported the antioxidant activity of 6 genotypes as between 1.24 and $2.71 \mu$ mol Trolox $100 \mathrm{~g}^{-1}$; Klymenko et al. (2019) in Ukraine, reported antioxidant activity of 20 genotypes as between 5.94 and16.56 $\mu \mathrm{mol}$ Trolox $\cdot \mathrm{g}^{-1}$. On the other hand, Kucharska et al. (2011) conducted a study in Poland on cornelian cherry gene sources and reported the greatest antioxidant activity for Dublany cultivar $\left(20.72 \mu \mathrm{mol}\right.$ Trolox $\left.\cdot \mathrm{g}^{-1}\right)$ and the lowest value for Juliusz cultivar $(10.85 \mu \mathrm{mol}$ Trolox $\left.\cdot \mathrm{g}^{-1}\right)$.

Total flavonoids of the present genotypes varied between $286.40 \mathrm{mg} \mathrm{QE} \cdot \mathrm{kg}^{-1}$ (G10) and 2,882.80 mg $\mathrm{QE} \cdot \mathrm{kg}^{-1}(\mathrm{G} 7)$ and a large variation was observed in total flavonoid contents of the genotypes.

Hassanpour et al. (2011) reported total flavonoids of cornelian cherry fruits in Iran as between 321.27 and $669.00 \mathrm{mg} \mathrm{QE} \cdot 100 \mathrm{~g}^{-1}$; Cosmulescu et al. (2019) reported total flavonoids of 6 cornelian cherry genotypes collected from different regions of Romania in the range of 12.14-64.48 mg QE · $100 \mathrm{~g}^{-1}$. Present findings on total flavonoids were lower than the values of Hassanpour et al. (2011) and greater than the values of Cosmulescu et al. (2019).

Total phenolics of the present genotypes varied between 2,644.80 $\mathrm{mg} \mathrm{GAE} \cdot \mathrm{kg}^{-1}$ (G2) and 12,959.00 mg $\mathrm{GAE} \cdot \mathrm{kg}^{-1}(\mathrm{G} 14)$.

In previous studies conducted with cornelian cherry fruits, Tural and Koca (2008) reported total phenolics of 24 genotypes selected from Black Sea region of Turkey as between 2.81 and $5.79 \mathrm{mg} \mathrm{GAE} \cdot \mathrm{g}^{-1}$; Y1lmaz et al. (2009) reported total phenolics of 16 genotypes collected from Western Black Sea and Inner Anatolia of Turkey range from 26.59 to $74.83 \mathrm{mg} \mathrm{GAE} \cdot \mathrm{g}^{-1}$; Hassanpour et al. (2011) reported total phenolics of cornelian cherry genotypes grown in Iran varied between 1,097.19 and 2,695.75 mg GAE · $100 \mathrm{~g}^{-1}$; Dragovic-Uzelac et al. (2007) reported total phenolics in Croatia as between 2,095 and 3,055 $\mathrm{mg} \mathrm{GAE} \cdot \mathrm{kg}^{-1}$. Present findings on total phenolics were greater than the values of Tural and Koca (2008), Y1lmaz et al. (2009) and Dragovic-Uzelac et al. (2007) and lower than the values of Hassanpour et al. (2011).

Considering the bioactive components of the genotypes, it was observed that yellow fruits generally had lower antioxidant activity and total phenolics; there were significant variations among the genotypes and present values were mostly greater than earlier reports. Although the differences are thought to be mainly caused by the variation of the examined varieties, differences in climate and soil characteristics, the geographical situation of the area where the cultivation is made, the type and time of harvest, the storage or processing of the crop, the method or periodic differences of the applied cultural processes, crop load, tree ages and fruit ripening levels cause significant differences on the final form and the amount of the phytochemical composition (Benvenuti et al., 2004; Y1lmaz et al., 2009; Ercisli et al., 2011; Gündüz et al., 2013; Ersoy et al., 2018b; Sochorova et al., 2019; Szot et al., 2019b; Bolat and Ikinci, 2020; Mertoglu et al., 2020).

\section{Physical characteristics of cornelian cherry genotypes}

The greatest fruit lengths were obtained from G9 and G14 genotypes whereas the greatest geometric mean diameters and surface areas were observed in G3, G4, G9 and G18 genotypes (Table 3). The lowest surface areas were observed in G2, G5 and G8 genotypes. On the other hand, G12 and G18 genotypes had the closest geometry to sphere, thus had the lowest shape index values.

The greatest projected area, equivalent diameter and perimeter values at horizontal orientation were observed in G9 and G14 genotypes, whereas the lowest values were observed in G2 and G8 genotypes (Table 4). The greatest values at vertical orientation were observed in G18 genotype and the lowest values were observed in G14 genotype.

Some shape parameters were calculated with the use of dimensional attributes of cornelian cherry fruit and the results are given in Table 5. According to elongation averages at horizontal orientation, the difference between fruit length and widths were greater in G5, G9, G14 and G17 genotypes than the others. Therefore, relevant genotypes had more ellipsoidal form than the other genotypes. Coating ratio of these genotypes to a circular sieve opening was also lower in these genotypes than the others. The fruits with a full circle geometry had a shape factor of 1 . At horizontal orientation, genotypes G1, G3 and G15 had the closest geometry to a circle. According to the elongation values at vertical orientation, all genotypes, except for G18, had close geometry to a circle and were able to largely cover a circular opening. The greatest shape factors at vertical orientation were observed in G2, G3, G8 and G14 genotypes.

PCA results are provided in Table 6. Two principle components (PC1 and PC2) were able to explain $92.56 \%$ of total variation in size and shape parameters of cornelian cherry genotypes. The variance elements explained by $\mathrm{PCl}$ included size and shape parameters of cornelian cherry fruits. PC2 directly explained the variance in size parameters.

Based on the size and the shape parameters, factor scores identified for each genotype were presented in a scatter plot (Figure 3). Based on variance elements, the genotypes different in terms of size and shape 


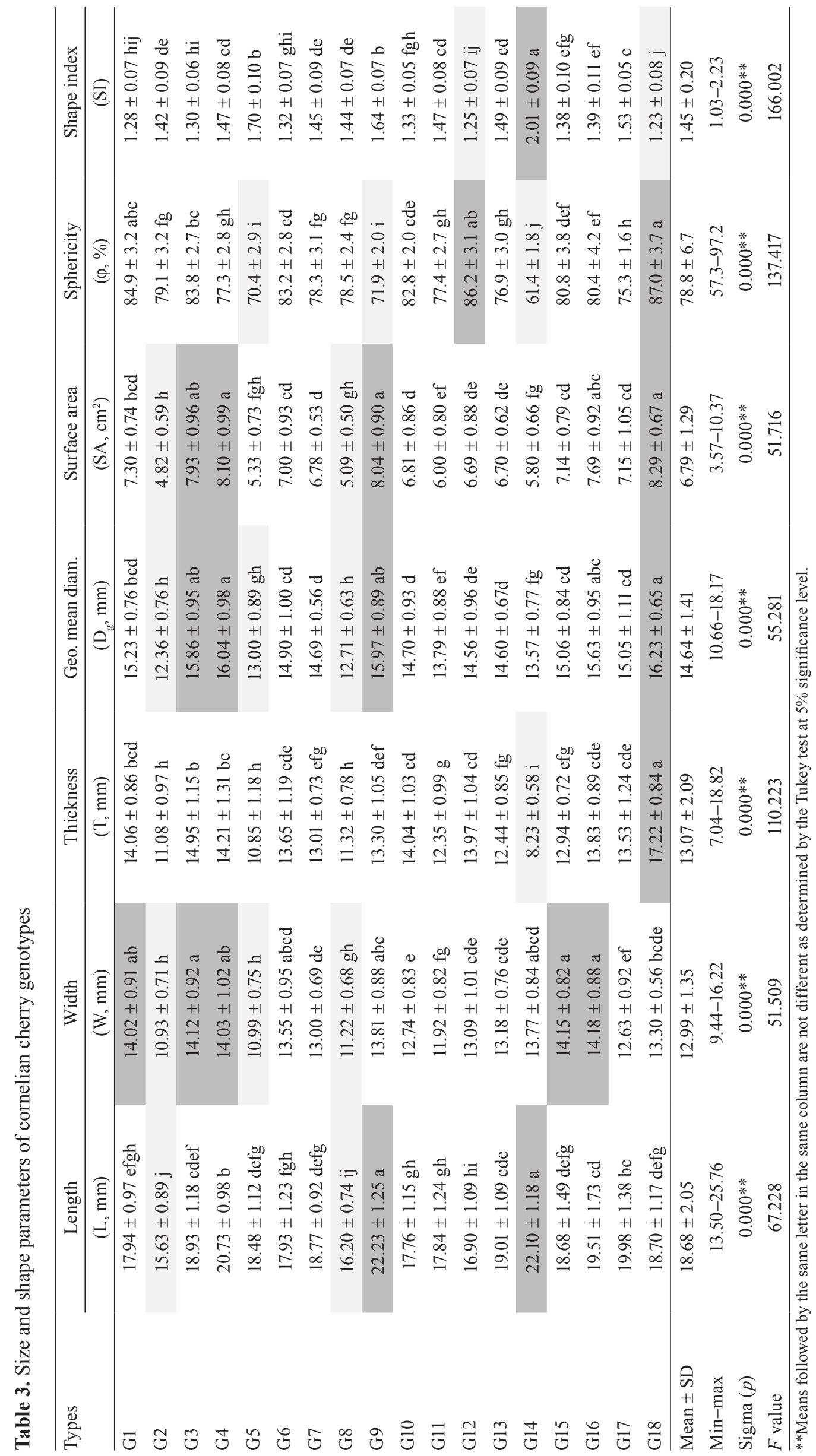


Table 4. Size and area parameters of cornelian cherry genotypes at horizontal and vertical orientations

\begin{tabular}{|c|c|c|c|c|c|c|}
\hline \multirow[t]{2}{*}{ Types } & \multicolumn{2}{|c|}{ Projected area $\left(\mathrm{mm}^{2}\right)$} & \multicolumn{2}{|c|}{ Equivalent diameter (mm) } & \multicolumn{2}{|c|}{ Perimeter $(\mathrm{mm})$} \\
\hline & Horizontal $\left(\mathrm{PA}_{\mathrm{h}}\right)$ & Vertical (PAv) & Horizontal $\left(\mathrm{ED}_{\mathrm{h}}\right)$ & Vertical $\left(\mathrm{ED}_{\mathrm{v}}\right)$ & Horizontal $\left(\mathrm{P}_{\mathrm{h}}\right)$ & Vertical $\left(\mathrm{P}_{\mathrm{v}}\right)$ \\
\hline G1 & $198.7 \pm 19.3 \mathrm{def}$ & $153.3 \pm 17.5 \mathrm{bc}$ & $15.9 \pm 0.8 \mathrm{cde}$ & $13.9 \pm 0.8 \mathrm{bc}$ & $54.1 \pm 2.6 \mathrm{de}$ & $47.2 \pm 3.1 \mathrm{cdef}$ \\
\hline G2 & $135.8 \pm 15.0 \mathrm{j}$ & $94.1 \pm 13.2 \mathrm{~h}$ & $13.1 \pm 0.7 \mathrm{~h}$ & $10.9 \pm 0.8 \mathrm{~g}$ & $45.2 \pm 2.7 \mathrm{~g}$ & $36.5 \pm 2.6 \mathrm{i}$ \\
\hline G3 & $213.5 \pm 24.6 \mathrm{~cd}$ & $166.0 \pm 20.4 \mathrm{ab}$ & $16.5 \pm 0.9 \mathrm{bcd}$ & $14.5 \pm 0.9 \mathrm{ab}$ & $56.0 \pm 3.2 \mathrm{~cd}$ & $48.6 \pm 2.9 \mathrm{bcd}$ \\
\hline G4 & $234.4 \pm 26.0 \mathrm{ab}$ & $150.9 \pm 20.5 \mathrm{bc}$ & $17.3 \pm 1.0 \mathrm{ab}$ & $13.8 \pm 0.9 \mathrm{bc}$ & $61.1 \pm 4.0 \mathrm{ab}$ & $48.6 \pm 3.6 \mathrm{bcd}$ \\
\hline G5 & $163.5 \pm 19.0 \mathrm{hi}$ & $90.9 \pm 14.1 \mathrm{~h}$ & $14.4 \pm 0.8 \mathrm{~g}$ & $10.7 \pm 0.8 \mathrm{~g}$ & $50.7 \pm 3.2 \mathrm{f}$ & $38.7 \pm 3.6 \mathrm{hi}$ \\
\hline G6 & $193.1 \pm 24.0 \mathrm{efg}$ & $142.7 \pm 21.0 \mathrm{~cd}$ & $15.7 \pm 1.0 \mathrm{def}$ & $13.4 \pm 1.0 \mathrm{~cd}$ & $53.4 \pm 3.4 \mathrm{def}$ & $47.8 \pm 6.0 \mathrm{cde}$ \\
\hline G7 & $193.1 \pm 17.4$ efg & $130.2 \pm 12.1 \mathrm{de}$ & $15.7 \pm 0.7 \mathrm{def}$ & $12.9 \pm 0.6 \mathrm{de}$ & $54.0 \pm 2.5 \mathrm{de}$ & $43.8 \pm 2.3 \mathrm{fg}$ \\
\hline G8 & $144.9 \pm 13.6 \mathrm{ij}$ & $98.7 \pm 11.3 \mathrm{gh}$ & $13.6 \pm 0.6 \mathrm{~h}$ & $11.2 \pm 0.6 \mathrm{~g}$ & $47.3 \pm 2.5 \mathrm{~g}$ & $37.4 \pm 2.2 \mathrm{i}$ \\
\hline G9 & $245.6 \pm 27.7 \mathrm{a}$ & $140.8 \pm 17.1 \mathrm{~cd}$ & $17.7 \pm 1.0 \mathrm{a}$ & $13.4 \pm 0.8 \mathrm{~cd}$ & $61.9 \pm 3.6 \mathrm{a}$ & $47.4 \pm 3.3 \mathrm{cde}$ \\
\hline G10 & $182.0 \pm 22.4 \mathrm{fgh}$ & $143.9 \pm 19.9 \mathrm{~cd}$ & $15.2 \pm 0.9$ efg & $13.5 \pm 0.9 \mathrm{~cd}$ & $52.0 \pm 3.2 \mathrm{ef}$ & $51.8 \pm 6.4 \mathrm{ab}$ \\
\hline G11 & $170.6 \pm 21.7 \mathrm{~h}$ & $113.8 \pm 16.5 \mathrm{fg}$ & $14.7 \pm 0.9 \mathrm{~g}$ & $12.0 \pm 0.8 \mathrm{f}$ & $52.3 \pm 4.5 \mathrm{ef}$ & $41.9 \pm 3.4 \mathrm{gh}$ \\
\hline G12 & $175.1 \pm 23.3 \mathrm{gh}$ & $145.2 \pm 20.6 \mathrm{~cd}$ & $14.9 \pm 1.0 \mathrm{fg}$ & $13.6 \pm 1.0 \mathrm{~cd}$ & $52.0 \pm 3.2 \mathrm{ef}$ & $46.4 \pm 3.3 \mathrm{cdef}$ \\
\hline G13 & $199.7 \pm 19.8 \mathrm{cdef}$ & $123.9 \pm 13.4 \mathrm{ef}$ & $15.9 \pm 0.8 \mathrm{cde}$ & $12.5 \pm 0.7$ ef & $54.6 \pm 2.7 \mathrm{de}$ & $45.4 \pm 4.5 \mathrm{defg}$ \\
\hline G14 & $245.2 \pm 25.4 \mathrm{a}$ & $57.6 \pm 8.1 \mathrm{i}$ & $17.6 \pm 0.9 \mathrm{a}$ & $8.5 \pm 0.6 \mathrm{~h}$ & $61.4 \pm 3.1 \mathrm{ab}$ & $28.5 \pm 2.0 \mathrm{k}$ \\
\hline G15 & $209.1 \pm 24.6 \mathrm{cde}$ & $140.2 \pm 17.3 \mathrm{~cd}$ & $16.3 \pm 1.0 \mathrm{~cd}$ & $13.3 \pm 0.8 \mathrm{~cd}$ & $55.4 \pm 3.6 \mathrm{~d}$ & $49.5 \pm 4.0 \mathrm{bc}$ \\
\hline G16 & $219.5 \pm 26.5 \mathrm{bc}$ & $151.7 \pm 18.2 b c$ & $16.7 \pm 1.0 \mathrm{bc}$ & $13.9 \pm 0.8 \mathrm{bc}$ & $58.7 \pm 4.1 \mathrm{bc}$ & $49.7 \pm 5.2 b c$ \\
\hline G17 & $203.0 \pm 26.2 \mathrm{cde}$ & $133.0 \pm 21.6 \mathrm{de}$ & $16.0 \pm 1.0 \mathrm{~cd}$ & $13.0 \pm 1.1 \mathrm{de}$ & $55.8 \pm 3.7 \mathrm{~cd}$ & $44.4 \pm 4.8 \mathrm{efg}$ \\
\hline G18 & $198.0 \pm 17.2 \mathrm{def}$ & $174.0 \pm 14.7 \mathrm{a}$ & $15.9 \pm 0.7 \mathrm{de}$ & $14.9 \pm 0.6 \mathrm{a}$ & $54.4 \pm 2.8 \mathrm{de}$ & $53.5 \pm 3.5 \mathrm{a}$ \\
\hline Mean \pm SD & $194.5 \pm 36.9$ & $130.5 \pm 33.0$ & $15.7 \pm 1.5$ & $12.8 \pm 1.7$ & $54.3 \pm 5.4$ & $44.8 \pm 7.1$ \\
\hline Min-max & $106.5-318.9$ & $42.1-212.7$ & 11.6-20.1 & $7.3-16.5$ & $39.7-71.3$ & $24.3-72.5$ \\
\hline $\operatorname{Sigma}(p)$ & $0.000 * *$ & $0.000 * *$ & $0.000 * *$ & $0.000^{* *}$ & $0.000 * *$ & $0.000^{* *}$ \\
\hline$F$ value & 56.941 & 88.199 & 59.775 & 105.217 & 53.947 & 74.787 \\
\hline
\end{tabular}

**Significant at $p<0.01$.

Means followed by the same letter in the same column are not different as determined by the Tukey test at $5 \%$ significance level.

Table 5. Shape parameters of cornelian cherry fruits at horizontal and vertical orientations

\begin{tabular}{|c|c|c|c|c|c|c|}
\hline \multirow[t]{2}{*}{ Types } & \multicolumn{2}{|c|}{ Shape factor } & \multicolumn{2}{|c|}{ Elongation } & \multicolumn{2}{|c|}{ Coating ratio $(\%)$} \\
\hline & Horizontal $\left(\mathrm{SF}_{\mathrm{h}}\right)$ & Vertical $\left(\mathrm{SF}_{\mathrm{v}}\right)$ & Horizontal $\left(\mathrm{E}_{\mathrm{h}}\right)$ & $\operatorname{Vertical}\left(\mathrm{E}_{\mathrm{v}}\right)$ & Horizontal $\left(\mathrm{CR}_{\mathrm{h}}\right)$ & Vertical $\left(\mathrm{CR}_{\mathrm{v}}\right)$ \\
\hline G1 & $0.850 \pm 0.013 \mathrm{ab}$ & $0.865 \pm 0.041 \mathrm{abc}$ & $1.28 \pm 0.09 \mathrm{~h}$ & $1.05 \pm 0.03 \mathrm{~b}$ & $78.63 \pm 5.01 \mathrm{a}$ & $94.6 \pm 2.4 \mathrm{a}$ \\
\hline G2 & $0.832 \pm 0.024 \mathrm{abcd}$ & $0.882 \pm 0.019 \mathrm{ab}$ & $1.43 \pm 0.07 \mathrm{~cd}$ & $1.06 \pm 0.03 b$ & $70.65 \pm 3.57 \mathrm{defg}$ & $93.6 \pm 2.7 \mathrm{ab}$ \\
\hline G3 & $0.851 \pm 0.014 \mathrm{a}$ & $0.881 \pm 0.010 \mathrm{ab}$ & $1.34 \pm 0.08 \mathrm{efgh}$ & $1.07 \pm 0.05 \mathrm{~b}$ & $75.79 \pm 3.92 \mathrm{abc}$ & $93.1 \pm 3.6 \mathrm{ab}$ \\
\hline G4 & $0.791 \pm 0.069 \mathrm{e}$ & $0.808 \pm 0.106 \mathrm{cdef}$ & $1.48 \pm 0.08 \mathrm{c}$ & $1.08 \pm 0.08 \mathrm{~b}$ & $69.31 \pm 3.78 \mathrm{fg}$ & $90.9 \pm 5.3 b$ \\
\hline G5 & $0.798 \pm 0.028 \mathrm{de}$ & $0.768 \pm 0.097 \mathrm{fg}$ & $1.68 \pm 0.07 \mathrm{a}$ & $1.09 \pm 0.05 b$ & $60.89 \pm 2.84 \mathrm{j}$ & $90.9 \pm 4.0 \mathrm{~b}$ \\
\hline G6 & $0.847 \pm 0.016 \mathrm{abc}$ & $0.794 \pm 0.102 \mathrm{def}$ & $1.32 \pm 0.07 \mathrm{fgh}$ & $1.06 \pm 0.04 \mathrm{~b}$ & $76.42 \pm 3.91 \mathrm{ab}$ & $93.2 \pm 3.6 \mathrm{ab}$ \\
\hline G7 & $0.830 \pm 0.015 \mathrm{abcd}$ & $0.854 \pm 0.048 \mathrm{abcd}$ & $1.45 \pm 0.08 \mathrm{~cd}$ & $1.06 \pm 0.05 b$ & $69.80 \pm 4.02 \mathrm{efg}$ & $93.2 \pm 3.8 \mathrm{ab}$ \\
\hline G8 & $0.813 \pm 0.050 \mathrm{cde}$ & $0.886 \pm 0.008 \mathrm{a}$ & $1.45 \pm 0.07 \mathrm{~cd}$ & $1.06 \pm 0.04 \mathrm{~b}$ & $70.26 \pm 3.23 \mathrm{defg}$ & $93.4 \pm 3.4 \mathrm{ab}$ \\
\hline G9 & $0.803 \pm 0.015 \mathrm{de}$ & $0.787 \pm 0.061 \mathrm{defg}$ & $1.61 \pm 0.06 \mathrm{~b}$ & $1.09 \pm 0.05 \mathrm{~b}$ & $63.17 \pm 2.54 \mathrm{ij}$ & $91.2 \pm 4.2 \mathrm{~b}$ \\
\hline G10 & $0.842 \pm 0.015 \mathrm{abc}$ & $0.693 \pm 0.142 \mathrm{~h}$ & $1.40 \pm 0.05 \mathrm{def}$ & $1.06 \pm 0.04 \mathrm{~b}$ & $73.32 \pm 2.55$ bcde & $92.7 \pm 2.9 \mathrm{ab}$ \\
\hline G11 & $0.788 \pm 0.082 \mathrm{e}$ & $0.815 \pm 0.078$ bcdef & $1.50 \pm 0.08 \mathrm{c}$ & $1.07 \pm 0.04 \mathrm{~b}$ & $68.18 \pm 4.23 \mathrm{gh}$ & $92.3 \pm 3.6 \mathrm{ab}$ \\
\hline G12 & $0.814 \pm 0.076$ bcde & $0.845 \pm 0.063$ abcde & $1.29 \pm 0.07 \mathrm{~h}$ & $1.05 \pm 0.04 \mathrm{~b}$ & $77.84 \pm 4.23 \mathrm{a}$ & $94.1 \pm 3.1 \mathrm{ab}$ \\
\hline G13 & $0.840 \pm 0.013 \mathrm{abc}$ & $0.766 \pm 0.108 \mathrm{fg}$ & $1.44 \pm 0.07 \mathrm{~cd}$ & $1.06 \pm 0.04 \mathrm{~b}$ & $70.40 \pm 3.63 \mathrm{defg}$ & $93.4 \pm 3.2 \mathrm{ab}$ \\
\hline G14 & $0.816 \pm 0.014$ bcde & $0.884 \pm 0.013 \mathrm{ab}$ & $1.61 \pm 0.08 \mathrm{~b}$ & $1.08 \pm 0.05 b$ & $63.89 \pm 2.98 \mathrm{ij}$ & $91.9 \pm 4.3 \mathrm{ab}$ \\
\hline G15 & $0.853 \pm 0.018 \mathrm{a}$ & $0.722 \pm 0.078 \mathrm{gh}$ & $1.32 \pm 0.10 \mathrm{gh}$ & $1.08 \pm 0.03 \mathrm{~b}$ & $76.50 \pm 5.56 \mathrm{ab}$ & $91.5 \pm 2.8 \mathrm{ab}$ \\
\hline G16 & $0.799 \pm 0.053 \mathrm{de}$ & $0.782 \pm 0.101 \mathrm{efg}$ & $1.38 \pm 0.12 \mathrm{defg}$ & $1.05 \pm 0.03 \mathrm{~b}$ & $73.80 \pm 6.77 \mathrm{bcd}$ & $94.1 \pm 2.4 \mathrm{ab}$ \\
\hline G17 & $0.815 \pm 0.017 \mathrm{bcde}$ & $0.852 \pm 0.076$ abcde & $1.58 \pm 0.06 \mathrm{~b}$ & $1.08 \pm 0.05 b$ & $64.58 \pm 2.32 \mathrm{hi}$ & $91.6 \pm 3.9 \mathrm{ab}$ \\
\hline G18 & $0.839 \pm 0.020 \mathrm{abc}$ & $0.769 \pm 0.076 \mathrm{fg}$ & $1.41 \pm 0.09 \mathrm{de}$ & $1.32 \pm 0.06 \mathrm{a}$ & $72.30 \pm 4.47 \mathrm{cdef}$ & $74.7 \pm 3.3 \mathrm{c}$ \\
\hline Mean \pm SD & $0.824 \pm 0.043$ & $0.815 \pm 0.095$ & $1.44 \pm 0.14$ & $1.08 \pm 0.08$ & $70.88 \pm 6.47$ & $91.62 \pm 5.57$ \\
\hline Min-max & $0.443-0.890$ & 0.338-0.907 & $1.15-1.85$ & $1.00-1.51$ & $55.14-87.61$ & 66.49-99.13 \\
\hline Sigma $(p)$ & $0.000 * *$ & $0.000 * *$ & $0.000 * *$ & $0.000 * *$ & $0.000^{* *}$ & $0.000 * *$ \\
\hline$F$ value & 9.870 & 17.217 & 68.204 & 55.580 & 54.083 & 47.072 \\
\hline
\end{tabular}

**Significant at $p<0.01$.

Means followed by the same letter in the same column are not different as determined by the Tukey test at $5 \%$ significance level. 
parameters were indicated within a coloured frame. While the genotypes G2 and G8 with a negative factor score on PC2 had the smallest size, the genotypes G4 and G9 had greater size data than the others. The genotype G14 with the lowest sphericity was placed on the left side of PC1 axis and apart from the

Table 6. Eigen statistics and vectors for two principle components

\begin{tabular}{lrr}
\hline Size and shape features & PC1 & PC2 \\
\hline Sphericity & 0.956 & \\
Shape index & -0.953 & \\
Projected area at vertical & 0.927 & \\
Thickness & 0.915 & \\
Perimeter at vertical & 0.891 & \\
Elongation at horizontal & -0.805 & \\
Projected area at horizontal & & 0.990 \\
Perimeter at horizontal & & 0.988 \\
Length & & 0.932 \\
Width & & 0.826 \\
Geometric mean diameter & & 0.767 \\
\hline Eigenvalue & 5.788 & 4.395 \\
Proportion (\%) & 52.614 & 39.950 \\
Cumulative (\%) & 52.614 & 92.564 \\
\hline
\end{tabular}

others. The genotype G5 exhibited a difference in elongation parameter.

When the physical attributes of 18 cornelian cherry genotypes were tested with PCA, it was observed that two principle components were able to explain a large portion of the variance in size and shape parameters. The physical characteristics of the genotypes G2, G4, G5, G8, G9 and G14, placed apart from the other genotypes on scatter plot, were remarkably different from the others.

\section{Visual comparison of cornelian cherry genotypes with elliptic Fourier analysis}

Two principle components identified based on shape descriptors explained $86.65 \%$ of total variance in cornelian cherry genotypes (Figure 4). According to $\mathrm{PC} 1$, the greatest shape difference (explained variance of $80.05 \%$ ) was attributed to genotypes with oval and circular geometry. Based on average shape geometry, it can be stated that cornelian cherry genotypes had an oval geometry. However, based on $\pm 2 \mathrm{SD}$ variations, it is possible to mention about pointed or spherical forms. According to PC2, shape differences were slightly (explained variance of $6.60 \%$ ) attributed to the droplike image of the fruits. According to elliptic Fourier analysis results, it can be stated that cornelian cherry genotypes had an oval appearance in shape geometry. However, there were some genotypes with a shape

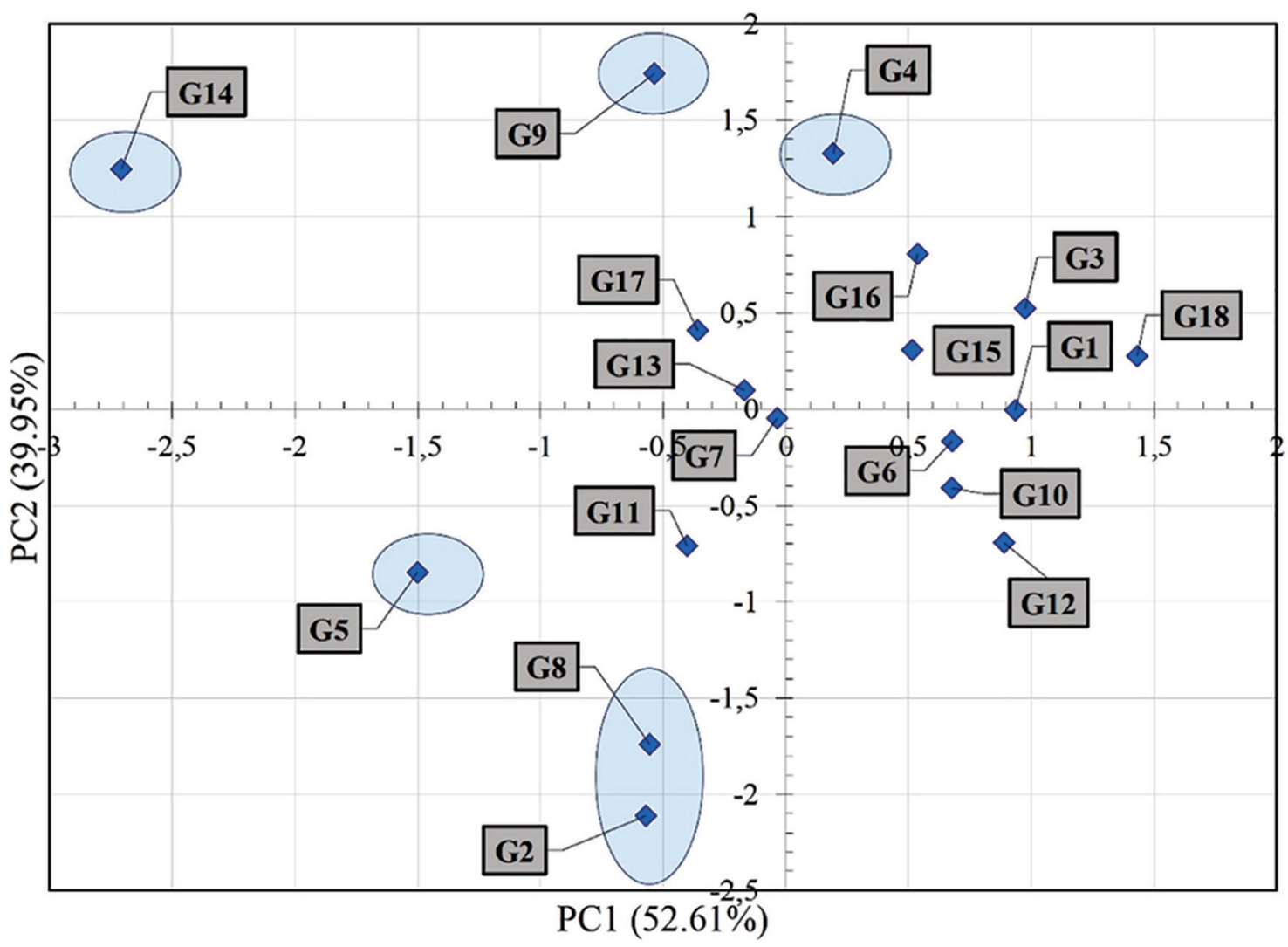

Figure 3. PCA scatter plot for the first two PCs explaining variations in size and shape parameters of cornelian cherry genotypes. 


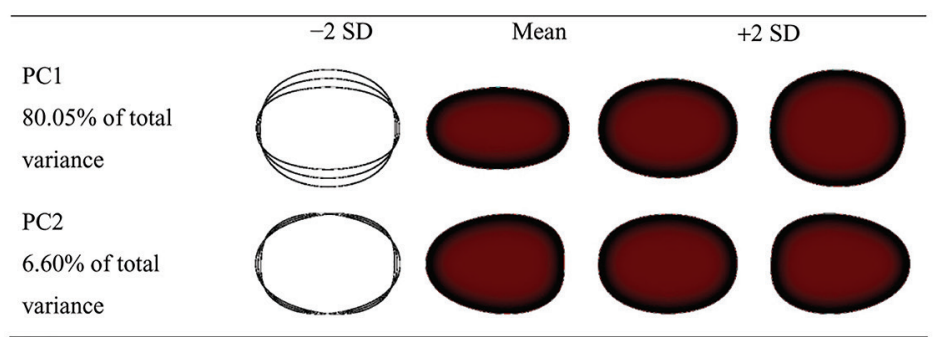

Figure 4. Variations in shape geometry of cornelian cherry geometry based on principle component scores obtained from elliptic Fourier descriptors (orifice contours from left to right: mean-2 SS, mean, mean+2 SS).

geometry close to a spherical form. Such a finding is especially significant for the geometry of sieve openings in size-based separation.

Results of multivariate variance analysis conducted to put forth the shape differences between cornelian cherry genotypes with the aid of EF method are provided in Table 7. The first two functions obtained from the discriminant analysis clearly put forth the shape differences of cornelian cherry genotypes and the entire variance was explained by these discriminant functions. Accordingly, the first function explained $78.6 \%$ and the second function explained $21.4 \%$ of the variation. According to Wilks' Lambda and Pillai Trace statistics, there were significant shape differences between the genotypes. Pair-wise comparisons were made in the Hotelling test and the genotypes with insignificant differences between them were indicated in coloured format. In shape assessments based on fruit contours, there were not any genotypes similar to G12 genotype.

Among the cornelian cherry genotypes, the groups with similar shapes were presented in coloured fashion in the scatter plot (Figure 5). Accordingly, 18 cornelian cherry genotypes were divided into 5 main shape groups. The first group included the genotypes G5, G9, G14 and G17; the second group included genotypes G4, G7, G8, G11 and G18; the third group included genotypes G2 and G13; the fourth group included genotypes G1, G3, G6, G10, G15 and G16; the fifth group included genotype G12.

In the present study, differences in physical characteristics of cornelian cherry genotypes were determined with PCA. Physical characteristics included size parameters and some shape parameters calculated accordingly. Elliptic Fourier method allowed comparisons based only on the shape, without considering size parameters. When common assessments were made based on two methods, it was observed that the genotypes G5, G9 and G14 with different size parameters have a similar appearance in shape.

\section{CONCLUSION}

Present findings revealed that 18 cornelian cherry genotypes collected from natural flora were quite rich in bioactive compounds. Antioxidant activity (55.062-152.420 $\left.\mathrm{mmolTE} \cdot \mathrm{kg}^{-1}\right)$, totalflavonoids (286.40-
2,882.80 $\left.\mathrm{mg} \mathrm{QE} \cdot \mathrm{kg}^{-1}\right)$ and total phenolics (2,644.80$1,2959.00 \mathrm{mg} \mathrm{GAE} \cdot \mathrm{kg}^{-1}$ ) of the genotypes exhibited variations in a broad range. Such findings indicated that self-incompatible, foreign-pollinating (Akçay and Yalçınkaya, 2003) cornelian cherry genotypes exhibited quite a large phenotypic variation even in narrow geography. Therefore, in selection studies mostly applied in breeding programmes for superior genotypes, precise and deep assessments should be made to reach expedient individuals, thus point-selection method should be applied for this purpose.

Physical characteristics of 18 cornelian cherry genotypes constitute a significant source of data for the design of new processing systems. Shape differences in biological products require product-specific processing technologies. In terms of postharvest processing technologies, the genotypes with similar shape contours are processed in the same machine, but special systems should be designed for different genotypes. Classification, drying, transportation and packaging systems are generally designed based on physical characteristics of the fruits. As sieves are used in size classification systems, sieve opening geometry and size are arranged based on physical characteristics. While sieve opening geometry is oval in walnut classification systems (Ercisli et al., 2012; Demir et al., 2018), circular geometry is used hazelnut classification systems (Sayınc1 et al., 2015b). In drying systems, the surface area of the product designates drying durations. For instance, average surface area of Prunus laurocerasus (cherry laurel) fruits (Sayinci et al., 2015a) is about twice as much of Cornus mas (cornelian cherry) fruits, thus such greater surface areas prolong drying durations. Product physical characteristics also designate the design of conveyor and elevator systems used for product transportation. Product characteristics should also be well-known in the design of pneumatic and mechanical systems of packaging units or the manufacture of moulds for packages.

It was concluded based on the present findings that cornelian cherry gene sources were quite rich in bioactive compounds. Geometric shapes and size parameters of 18 cornelian cherry genotypes were precisely determined and shape differences were determined with elliptic Fourier analysis and physical parameters were successfully compared with the multivariate statistical approaches. 


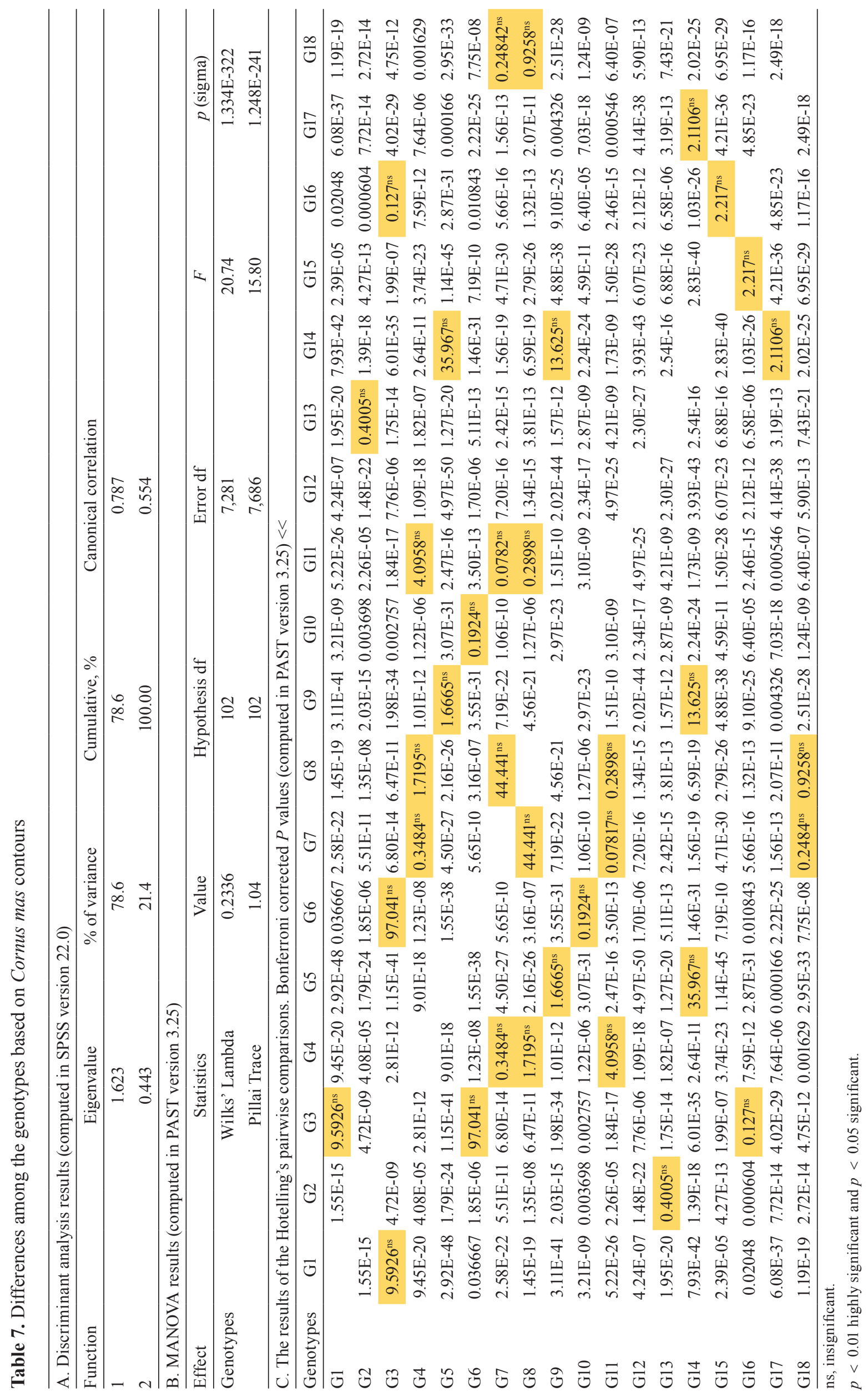




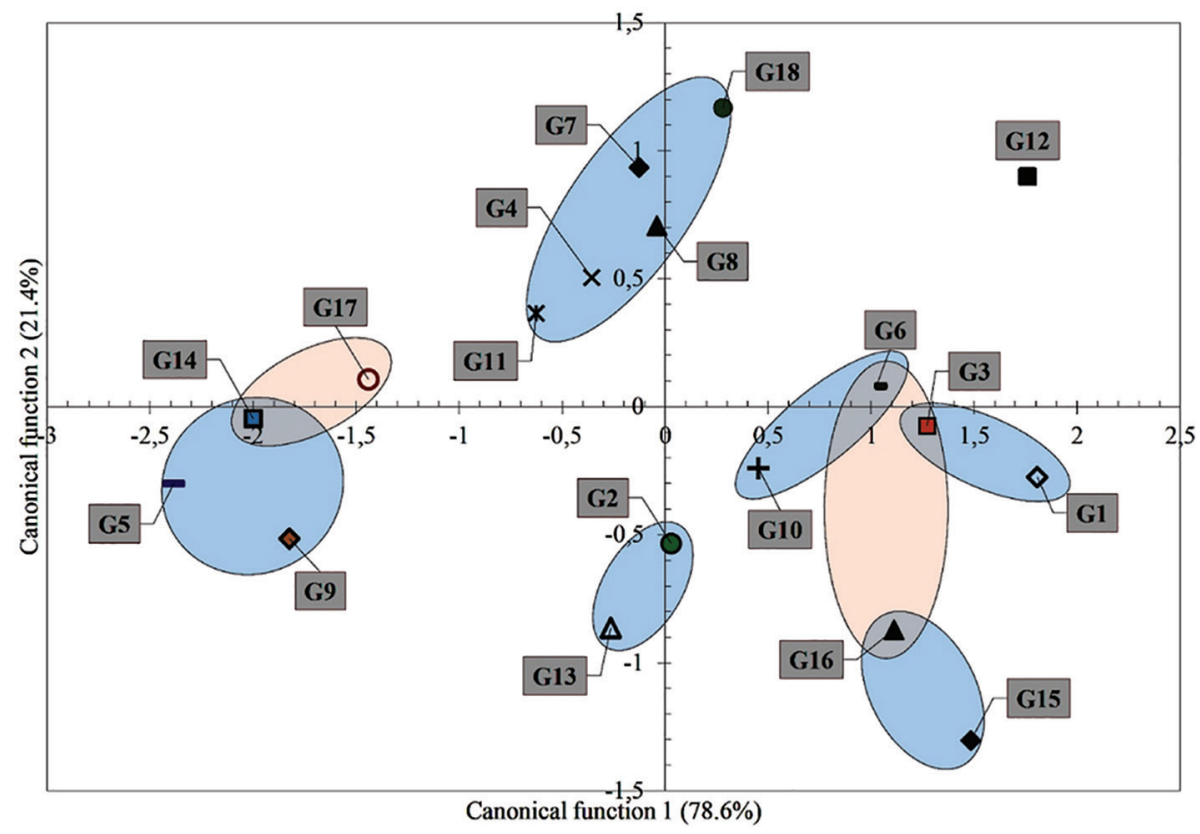

Figure 5. Group centroids of Cornus mas genotypes at canonical discriminant functions.

\section{FUNDING}

This research was not funded.

\section{AUTHOR CONTRIBUTIONS}

All the authors contributed equally to all aspects of this manuscript.

\section{CONFLICT OF INTEREST}

The authors declare no conflict of interest.

\section{REFERENCES}

AkÇAy, M. E., And YalçınKaya, E. (2003). Yalova'da Yetiştiriciliği Yapılan Bazı Kızılcık (Cornus mas L.) Tiplerinin Döllenme Biyolojisi Üzerine Araştırmalar. Türkiye IV. Ulusal Bahçe Bitkileri Kongresi (pp. 280-281). Antalya, Turkey.

AkpunAR, E. (2015). Türk Lokumu Üretiminde Kızllcık (Ergen) Meyvesinin Doğal Renklendirici Olarak Kullanılmasi ve Depolama Stabilitesinin Araştırılmast. Afyon Kocatepe Üniversitesi, Fen Bilimleri Enstitüsü, Gıda Mühendisliği Ana Bilim Dalı, Yüksek Lisans Tezi.

Benvenuti, S., Pellati, F., Melegari, M., and Bertelli, D. (2004). Polyphenols, anthocyanins, ascorbic acid, and radical scavenging activity of Rubus, Ribes, and Aronia. Journal of Food Science, 69(3), 164-169.

Beyhan, Ö., Elmastaş, M., And Gedikli, F. (2010). Total phenolic compounds and antioxidant capacity of leaf, dry fruit and fresh fruit of feijoa (Acca sellowiana, Myrtaceae). Journal of Medicinal Plants Research, 4, 1065-1072.

Bijelic, S., Golosin, B., Todorovic, J. N., And Cerovic, S. (2011). Morphological characteristics of best
Cornelian cherry (Cornus mas L.) genotypes selected in Serbia. Genetic Resources and Crop Evolution, 58, 689-695.

BolAt, I., AND Ikinci A. (2020). Investigation on heat requirements and fruit growth of some early maturing apricot cultivars in semiarıd conditions. Fresenius Environmental Bulletin, 29(3), 1542-1549.

Bozdogan, A. (2017). Viscosity and physicochemical properties of cornelian cherry (Cornus mas L.) concentrate. Food Measure, 11, 1326-1332.

Brand-Williams, W., Cuvelier, M. E., and Berset, C. L. W. T. (1995). Use of a free radical method to evaluate antioxidant activity. LWT-Food Science and Technology, 28, 25-30.

Brindza, P., Brindza, J., Toth, D., Klimenko, S. V., And Grigorieva, O. (2009). Biological and commercial characteristics of cornelian cherry (Cornus mas L.) population in the Gemer region of Slovakia. Acta Horticulturae, 818, 85-94.

Celep, E., Aydin, A., Kirmizibekmez, H., and Yesilada, E. (2013). Appraisal of in vitro and in vivo antioxidant activity potential of cornelian cherry leaves. Food and Chemical Toxicology, 62, 448-455.

Chang, C. C., Yang, M. H., Wen, H. M., and Chern, J. C. (2002). Estimation of total flavonoid content in propolis by two complementary colorimetric methods. Journal of Food and Drug Analysis, 10, 13-21.

Coksoyler, D. E. (2018). Kuzılcık çekirdeğinden elde edilen aktif karbonun tekstil boyar maddesi olan rhodamine B'yi adsorplama özellikleri. Trakya Üniversitesi, Fen Bilimleri Enstitüsü, Kimya Anabilim Dalı, Yüksek Lisans Tezi.

Colak, A. M., Kupe, M., Bozhuyuk, R. M., Ercisli, S., And Gundogdu, M. (2019). Identification of some fruit characteristics in wild bilberry (Vaccinium 
myrtillus L.) accessions from Eastern Anatolia. Gesunde Pflanzen, 70, 31-38.

Cosmulescu, S., Trandafir, I., And Cornescu, F. (2019). Antioxidant capacity, total phenols, total flavonoids and colour component of cornelian cherry (Cornus mas L.) wild genotypes. Notulae Botanicae Horti Agrobotanici, 47(2), 390-394.

Da Ronch, F., Caudullo, G., Houston Durrant, T. And DE Rigo D. (2016). Cornus mas in Europe: Distribution, habitat, usage and threats. European atlas of forest tree species (pp. 82-83). Publication Office of the European Union, Luxembourg.

Demir, B., Sayinci, B., Çetin, N., Yaman, M., Çömlek, R., Aydin, Y., AND Sütyemez, M. (2018). Elliptic Fourier based analysis and multivariate approaches for size and shape distinctions of walnut (Juglans regia L.) genotypes. Grasas y Aceites, 69(4), 1-12.

Deng, S., West, B. J., and Jensen, C. J. (2013). UPLCTOF-MS characterization and identification of bioactive iridoids in Cornus mas fruit. Journal of Analytical Methods in Chemistry, 2013(8), 710972.

Didin, M., Kizilaslan, A., And FenercioĞLu, H. (2000). Malatya'da yetiştirilen bazı kızılcık çeşitlerinin nektara işlenmeye uygunluklarının belirlenmesi üzerinde bir araştırma. GIDA, 25(6), 435-441.

Dragovic-Uzelac, V., Levaj, B., Bursac, D., Pedisic, S., Radojcic, I., AND Bisko, A. (2007). Total phenolics and antioxidant capacity assays of selected fruits. Agriculturae Conspectus Scientificus, 72(4), 279-284.

Elgin, Ş. (2019). Klzılcık (Cornus mas) ekstresi ilaveli pişirilmiş köftelerin donmuş muhafazası sırasında fizikokimyasal özelliklerinin incelenmesi. Pamukkale Üniversitesi, Fen Bilimleri Enstitüsü, Gıda Mühendisliği Ana Bilim Dalı, Yüksek Lisans Tezi.

Ercisli, S., IpeK, A., And Barut, E. (2011). SSR markerbased DNA fingerprinting and cultivar identification of olives (Olea europaea). Biochemical Genetics, 49(9-10), 555-561.

Ercisli, S., Orhan, E., Esitken, A., Yildirim, N., And Agar, G. (2008). Relationships among some cornelian cherry genotypes (Cornus mas L.) based on RAPD analysis. Genetic Resources and Crop Evolution, 55(4), 613-618.

Ercisli, S., Sayinci, B., Kara, M., Yildiz, C., And Ozturk, I. (2012). Determination of size and shape attributes of walnut (Juglans regia L.) genotypes using image processing. Scientia Horticulturae, 133, 47-55.

Ergezer, H., Gökçe, R., Elgin, Ş., And AkCAN, T. (2018). Kızılcık (Cornus mas L.) ekstraktı kullanımının sucuk kalite karakteristikleri üzerine etkisi, Pamukkale Üniversitesi Mühendislik Bilimleri Dergisi, 24(7), 1376-1381.

Ersoy, N., Kupe, M., Gundogdu, M., Ilhan, G., And ErcisLi, S. (2018a). Phytochemical and antioxidant diversity in fruits of currant (Ribes spp.) cultivars,
Notulae Botanicae Horti Agrobotanici, 46(2), 381-387.

Ersoy, N., Kupe, M., Sagbas, H. I., And Ercisli, S. (2018b). Phytochemical diversity among barberry (Berberis vulgaris L.), Notulae Botanicae Horti Agrobotanici, 46(2),198-204.

Eyde, R. H. (1988). Comprehending Cornus: puzzles and progress in the systematics of the dogwoods. The Botanical Review, 54(3), 233-351.

FAOSTAT. (2018). Retrieved from http://www.fao.org/ faostat/en/\#data/QC. Accessed 15/04/2020.

Firatligil-Durmuş,E., ŠÁrka,E.,Bubní,,Z., Schejbal, M., and Kadlec, P. (2010). Size properties of legume seeds of different varieties using image analysis. Journal of Food Engineering, 99(4), 445-451.

FOODDATA CENTRAL. (2019). Retrieved from https:// fdc.nal.usda.gov/fdc-app.html\#/food-details/171722/ nutrients. Accessed 15/04/2020.

Gundesli M. A., Korkmaz, N., And Okatan, V. (2019). Polyphenol content and antioxidant capacity of berries: A review. International Journal of Agriculture Forestry and Life Sciences, 3(2), 350-361.

Gündüz, K., SaraçoĞlu, O., Özgen, M., and Serçe, S. (2013). Antioksidant, Physical and chemical characteristics of Cornelian Cherry fruits (Cornus mas L.) at different stages of ripeness. Acta Scientiarum Polonorum, Hortorum Cultus 12(4), 59-66.

Hammer, Ø., Harper, D. A. T., And Ryan, P. D. (2001). PAST: Paleontological statistics software package for education and data analysis. Palaeontologia Electronica, 4(1), 1-9.

Hassanpour, H., Hamidoghli, Y., Hajilo, J., AND Adlipour, M. (2011). Antioxidant capacity and phytochemical properties of cornelian cherry (Cornus mas L.) genotypes in Iran. Scientia Horticulturae, 129, 459-463.

Iwata, H., AND UKaI, Y. (2002). SHAPE: A computer program package for quantitative evaluation of biological shapes based on elliptic Fourier descriptors. Journal of Heredity, 93, 384-385.

Kara, M. (2017). Biyolojik Ürünlerin Fiziksel Ürünleri (Tarımsal Ürün ve Gıdaları İçerir). Güven ${ }^{\circledR}$ Bilimsel, İzmir, Birinci Baskl, ISBN: 978-975-6240-56-4, 327s (in Turkish).

Klimenko, S. (2004). The Cornelian cherry (Cornus mas L.); collection, preservation and utilization of genetic resources. Journal of Fruit and Ornamental Plant Research, 12(2), 93-98.

Klymenko, S., Kucharska, A.Z., Sokol-Letowska, A., And Piorecki. N. (2019). Antioxidant activities and phenolic compounds in fruits of cultivars of cornelian cherry (Cornus mas L.). Agrobiodiversity for improving nutrition. Health and Life Quality, (3), 484-499.

Kucharska, A.Z.(2012). Active Compounds of Cornelian Cherry Fruit (Cornus mas L.) Wydawnictwo Uniwersytetu Przyrodniczego Wrocław, Poland. 
Kucharska, A. Z., Sokol-Lętowska, A., And Piorecki, N. (2011). Morphological, physical \& chemical, and antioxidant profiles of polish varieties of cornelian cherry fruit (Cornus mas L.). Żywność Nauka Technologia Jakość (Poland), 3, 78-89.

Kucharska, A. Z., Szumny, A., Soko-Letowska, A., Piorecki, N., and Klymenko, S. V. (2015). Iridoids and anthocyanins in cornelian cherry (Cornus mas L.) cultivars. Journal of Food Composition and Analysis, 40, 95-102.

Mertoglu, K., Evrenosoglu, Y., and Polat, M. (2019). Combined effects of ethephon and mepiquat chloride on late blooming, fruit set, and phytochemical characteristics of Black Diamond plum. Turkish Journal of Agriculture \& Forestry, 43(6), 544-553.

Mertoglu, K., Gülbandilar, A., And Bulduk, İ. (2020). Growing conditions effect on fruit phytochemical composition and anti-microbial activity of plum (cv. Black Diamond). International Journal of Agriculture Forestry and Life Sciences, 4(1), 56-61.

Mikaili, P., Koohirostamkolaei, M., Babaeimarzangou, S. S., Aghajanshakeri, S., Moloudizargari, M., Gamchi, N. S., and Toloomoghaddam, S. (2013). Therapeutic uses and pharmacological effects of Cornus mas: a review. Journal of Pharmaceutical and Biomedical Sciences, 35, 1732-1738.

Mohsenin, N. N. (1986). Physical properties of plant and animal materials. New York, NY: Gordon and Breach Science Publishers.

Neto, J. C., Meyer, G. E., Jones, D. D., and Samal, A. K. (2006). Plant species identification using Elliptic Fourier leaf shape analysis. Computers and Electronics in Agriculture, 50, 121-134.

Okan, O., Serencam, H., Baltas, N., and Can, Z. (2019). Some edible forest fruits their in vitro antioxidant activities, phenolic compounds and some enzyme inhibition effects. Fresenius Enviromental, 28(8), 6090-6098.

Olajide, J. O., And Ade-Omowaye, B. I. O. (1999). Some physical properties of locust bean seed. Journal of Agricultural Engineering Research, 74, 213-215.

Ozgen, F. (2015). Experimental investigation of drying characteristics of cornelian cherry fruits (Cornus mas L.). Heat Mass Transfer, 51, 343-352.

ÖZKAn-KocA, A. (2012). Ortadoğu'da yayılış gösteren Apis mellifera L. (Hymenoptera: Apidae) alttürlerinin geometrik morfometri yöntemiyle analizi. Ankara Üniversitesi Fen Bilimleri Enstitüsü, Biyoloji Anabilim Dalı (Doktora Tezi), Ankara, 167 s.

SAYINCI, B. (2016). Poliasetal (POM) meme plakalarının orifis geometrisinde üretim kusurlarının eliptik fourier tanımlayıc1larıyla tespiti. Uluda $\breve{g} \ddot{\text { niversitesi }}$ Ziraat Fakültesi Dergisi, 30(1), 57-73.

Sayınci, B., Ercișli, S., Akbulut, M., Şavşatli, Y., AND BAYKal, H. (2015a). Determination of shape in fruits of cherry laurel (Prunus laurocerasus) accessions by using Elliptic Fourier analysis. Acta Scientiarum Polonorum, Hortorum Cultus, 14(1), 63-82.

SAyinci, B., Kara, M., Ercișli, S., Duyar, Ö., And ERTÜRK, Y. (2015b). Elliptic Fourier analysis for shape distinction of Turkish hazelnut genotypes. Erwerbs-Obstbau, 57(1), 1-11.

SElÇUK, E., AND ÖZRENK, K. (2011). Erzincan yöresinde yetiştirilen kızılcıkların (Cornus mas L.) fenolojik ve pomolojik özelliklerinin belirlenmesi. I Ĭd dır Üniversitesi Fen Bilimleri Enstitüsü Dergisi, 1(4), 23-30.

Sochorova, L., Kleidus, B., Baron, M., Jurikova, T., Mlcek, J., Sochor, J., Ercisli, S., And Kupe, M. (2019). Assessment of antioxidants by HPLC-MS in grapevine seeds. Acta Scientiarum Polonorum, Hortorum Cultus, 18, 17-28.

Szot, I., Lipa, T., And Sosnowska, B. (2019a). Evaluation of yield and fruit quality of several ecotypes of cornelian cherry (Cornus mas L.) in Polish conditions. Acta Scientiarum Polonorum, Hortorum Cultus, 18(6), 141-150.

Szot, I., Szot, P., Lipa, T., Sosnowska, B., And Dobrzański, B. (2019b). Determination of physical and chemical properties of cornelian cherry (Cornus mas L.) fruits depending on degree of ripening and ecotypes. Acta Scientiarum Polonorum, Hortorum Cultus, 18(2), 251-262.

Tubives. (2020). Retrieved from http://194.27.225.161/ yasin/tubives/index.php?sayfa $=1 \&$ tax_id $=4505$. Accessed 15/04/2020.

Tural, S., And KocA, İ. (2008). Physico-chemical and antioxidant properties of cornelian cherry fruits (Cornus mas L.) grown in Turkey. Scientia Horticulturae, 116, 362-366.

West, B. J., Deng, S., Jensen, C. J., Palu, A. K., AND Berrio, L. F. (2012). Antioxidant, toxicity, and iridoid tests of processed Cornelian cherry fruits. International Journal of Food Science and Technology, 47(7), 1392-1397.

Yilmaz, K. U., Ercisli, S., Zengin, Y., Sengul, M., And Kafkas, E. Y. (2009). Preliminary characterisation of cornelian cherry (Cornus mas L.) genotypes for their physico-chemical properties. Food Chemistry, $114,408-412$.

Received: July 08, 2020; accepted: August 18, 2020. 